Odessa State Environmental University, 15, Lvovskaya str., Odessa, Ukraine

E-mail: smirnovandvla@gmail.com

\title{
ADVANCED RELATIVISTIC APPROACH IN SPECTROSCOPY OF COMPLEX AUTOIONIZATION RESONANCES IN ATOMIC SPECTRA
}

\begin{abstract}
We applied a generalized energy approach (Gell-Mann and Low S-matrix formalism) combined with the relativistic multi-quasiparticle (QP) perturbation theory (PT) with the Dirac-Kohn-Sham zeroth approximation and accounting for the exchange-correlation, relativistic corrections to studying autoionization resonances in the helium spectrum, in particular, we predicted the energies and widths of the number of the Rydberg resonances. There are presented the results of comparison of our theory data for the autoionization resonance $3 \mathrm{~s} 3 \mathrm{p} 1 \mathrm{P} 0$ with the available experimental data and those results of other theories, including, method of complex rotation by Ho, algebraic approach by Wakid-Callaway, diagonalization method by Senashenko-Wague etc.
\end{abstract}

\section{Introduction}

The knowledge of autoionization states properties of atomic systems is of a great importance note for many applications in atomic and molecular physics, plasma chemistry and physics, laser physics and quantum electronics etc. [1-52]. In this paper, which goes on our studying autoionization phenomena in different atomic systems, we present an advanced new relativistic approach [11-15] to relativistic calculating autoionization resonances (AR) characteristics of the helium atom. The new elements of the approach include the combined the generalized energy approach and the gauge-invariant relativistic many-body perturbation theory (PT) with the Dirac-KohnSham (DKS) "0" approximation (optimized 1QP representation) and an accurate accounting for relativistic, correlation and others effects. The generalized gauge-invariant version of the energy approach has been further developed in Refs. $[12,13]$.

\section{Relativistic perturbation theory approach in spectroscopy of autoionization states}

In refs. [11-15, 17-20] the fundamentals of the relativistic many-body PT formalism have been in details presented, so further we are limited only by the novel elements. Let us remind that the majority of complex atomic systems possess a dense energy spectrum of interacting states. In refs. [11-15, 17-20] it is realized a field procedure for calculating the energy shifts $\Delta \mathrm{E}$ of degenerate states, which is connected with the secular matrix $M$ diagonalization [8-12]. The whole calculation of the energies and decay probabilities of a nondegenerate excited state is reduced to the calculation and diagonalization of the $M$. The complex secular matrix $M$ is represented in the form $[9,10]$ :

$$
M=M^{(0)}+M^{(1)}+M^{(2)}+M^{(3)} .
$$

where $M^{(0)}$ is the contribution of the vacuum diagrams of all order of PT, and $M^{(1)}, M^{(2)}, M^{(3)}$ those of the one-, two- and three-QP diagrams respectively. The diagonal matrix $M^{(1)}$ can be presented as a sum of the independent 1QP contributions. The optimized 1-QP representation is the best one to determine the zeroth approximation. In the second order, there is important kind of diagrams: the ladder ones. These contributions have been summarized by a modification of the central potential, which must now include the screening (anti-screening) effect of each particle by two others. The additional potential modifies the 1QP orbitals and energies. 
A width of a state associated with the decay of the AR is determined by square of the matrix element of the interparticle interaction $\Gamma \infty \mid V\left(\beta_{1} \beta_{2}\right.$, $\left.\beta_{3} k\right)\left.\right|^{2}$. The total width is given by the expression:

$$
\begin{aligned}
& \Gamma\left(n_{1}^{0} j_{1}^{0}, n_{2}^{0} j_{2}^{0} ; J\right)=\frac{2 \pi}{K_{0}} \sum_{\beta_{1} \beta_{2}} \sum_{\beta_{1}^{\prime} \beta_{2}^{\prime}} C^{J}\left(\beta_{1} \beta_{2}\right) \times \\
& \times C^{J}\left(\beta_{1}^{\prime} \beta_{2}^{\prime}\right) \sum_{\beta \beta_{K}} V_{\beta_{1} \beta_{2} ; \beta \beta_{K}} V_{\beta_{K} \beta ; \beta_{1}^{\prime} \beta_{2}^{\prime}}
\end{aligned}
$$

where the coefficients $\mathrm{C}$ are in details described, for example, in Refs. [1-5]. The matrix element of the relativistic inter-particle interaction

$$
V\left(r_{i} r_{j}\right)=\exp \left(i \grave{u}_{j} r_{j}\right) \cdot\left(1-\dot{a}_{i} \dot{a}\right) / r_{j}
$$

(here $\alpha_{I}-$ the Dirac matrices) in (3) is determined as follows:

$$
\begin{aligned}
& V \\
& \beta_{1} \beta_{2} ; \beta_{4} \beta_{3}=\sqrt{\left(2 j_{1}+1\right)\left(2 j_{2}+1\right)\left(2 j_{3}+1\right)\left(2 j_{4}+1\right)} \times \\
& \times(-1)^{j_{1}+j_{2}+j_{3}+j_{4}+m_{1}+m_{2}} \times \\
& \mathrm{x} \sum_{a \mu}(-1)^{\mu}\left(\begin{array}{rrr}
j_{1} & j_{3} & a \\
m_{1}-m_{3} & \mu
\end{array}\right)\left(\begin{array}{rrr}
j_{2} & j_{4} & a \\
m_{2}-m_{4} & \mu
\end{array}\right) \times \\
& \times Q_{a}\left(n_{1} l_{1} j_{1} n_{2} l_{2} j_{2} ; n_{4} l_{4} j_{4} n_{3} l_{3} j_{3}\right), \\
& Q_{a}=Q_{a}^{\mathrm{Qul}}+Q_{a}^{\mathrm{B}} .
\end{aligned}
$$

Here $Q_{a}^{\mathrm{Qul}}$ and $Q_{a}^{\mathrm{B}}$ is corresponding to the Coulomb and Breit parts of the interparticle interaction (5). The calculating of all matrix elements, wave functions, Bessel functions etc is reduced to solving the system of differential equations. The formulas for the autoionization (Auger) decay probability include the radial integrals $R_{\alpha}(\alpha k \gamma \beta)$, where one of the functions describes electron in the continuum state. When calculating this integral, the correct normalization of the wave functions is very important, namely, they should have the following asymptotic at $r \rightarrow 0$ :

$$
\left.\begin{array}{l}
f \\
g
\end{array}\right\} \rightarrow(\lambda \omega)^{-1 / 2}\left\{\begin{array}{l}
{\left[\omega+(\alpha Z)^{-2}\right]^{-1 / 2} \sin (k r+\delta),} \\
{\left[\omega-(\alpha Z)^{-2}\right]^{-1 / 2} \cos (k r+\delta) .}
\end{array}\right.
$$

The important aspect of the whole procedure is an accurate accounting for the exchange-correlation effects. We have used the generalized relativistic Kohn-Sham density functional [33-35] in the zeroth approximation of relativistic PT; naturally, the perturbation operator contents the operator (3) minus the cited Kohn-Sham density functional. Further the wave functions are corrected by accounting of the first order PT contribution. Besides, we realize the procedure of optimization of relativistic orbitals base. The main idea is based on using ab initio optimization procedure, which is reduced to minimization of the gauge dependent multielectron contribution $\operatorname{Im} \delta E_{\text {ninv }}$ of the lowest QED PT corrections to the radiation widths of atomic levels. According to [35-37], "in the fourth order of QED PT (the second order of the atomic PT) there appear the diagrams, whose contribution to the $\operatorname{Im} \delta \mathrm{E}_{\text {ninv }}$ accounts for correlation effects and this contribution is determined by the electromagnetic potential gauge (the gauge dependent contribution)". The accurate procedure for minimization of the functional $\operatorname{Im} \delta \mathrm{E}_{\text {ninv }}$ leads to the Dirac-Kohn-Sham-like equations for the electron density that are numerically solved by the Runge-Cutta standard method It is very important to known that the regular realization of the total scheme allow to get an optimal set of the 1QP functions and more correct results in comparison with so called simplified one, which has been used in Refs. [34-34] and reduced to the functional minimization using the variation of the correlation potential parameter $b$. Other details can be found in refs.[10-13,16-20,41-74] as well as description of the "Superatom" and Cowan PC codes, used in all computing.

\section{Results and conclusion}

In the Table 1 we present the comparison of our advanced data for the AR $3 \mathrm{~s} 3 \mathrm{p}^{1} \mathrm{P}_{0}$ with those of other theories, including, method of complex rotation by Ho, algebraic approach by WakidCallaway, diagonalization method by Senashen- 
ko-Wague, relativistic Hartree-Fock (RHF) method by Nicolaides-Komninos, R-matrix method by Hayes-Scott, method of the adiabatic potential curves by Koyoma-Takafuji-Matsuzawa and Sadeghpour, $\mathrm{L}^{2}$ technique with the Sturm decomposition by Broad- Gershacher and Moccia-Spizzo, the Feshbach method by Wu-Xi) and data measurements in laboratories: NIST (NBS; $2 \mathrm{SO}-\mathrm{MeV}$ electron synchrotron storage ring (SURF-II )), Wisconsin Laboratory (Wisconsin Tantalus storage ring), Stanford Synchrotron Radiation Laboratory (SSRL), Berlin electron storage ring (BESSY), Daresbury Synchrotron Radiation Source (DSRS) [1,3,5,22-24].

Table 1a

Theoretical data for energy of the AR $3 \mathrm{~s} 3 \mathrm{p}{ }^{1} \mathbf{P}_{0}$ (our data with those of other theories)

\begin{tabular}{|l|c|c|}
\hline Method/Data & $\operatorname{Er}(\mathrm{eB})$ & $\Gamma / 2(\mathrm{eB})$ \\
\hline Our & 69.9113 & 0.1912 \\
ACC & 69.8892 & 0.1891 \\
Diagon. method & 69.9096 & 0.1491 \\
RHF & 69.8703 & - \\
APC1 & 69.8103 & - \\
L $^{2}$ tech. & 69.8737 & 0.1915 \\
Feshbach th. & 69.8991 & 0.1143 \\
K-matrix L & 69.8788 & 0.1839 \\
PT- Svin & 69.9055 & 0.1854 \\
CR method & 69.8722 & 0.1911 \\
MC HF & 69.8703 & - \\
R-matrix & 69.8797 & 0.1796 \\
E:Wisconsin & $69.917 \pm 0.012$ & $0.178 \pm 0.012$ \\
E: SSRL-1987 & $69.917 \pm 0.012$ & $0.178 \pm 0.012$ \\
E: BESSY & $69.914 \pm 0.015$ & $0.200 \pm 0.020$ \\
E: DSRS & $69.880 \pm 0.022$ & $0.180 \pm 0.015$ \\
\hline
\end{tabular}

Note: ACC- Algebraic close coupling; APC - Adiabatic potential curves; CR method-method of complex rotation; DM method - Diagonalization method

On the one hand, there is sufficiently good accuracy of our theory, the secondly (bearing in mind that most of the listed methods are developed specifically for the study helium and can not be easily generalized to the case of the heavy multi-electron atoms) the definite advantage of the presented approach. In Table 2 we present the resonance energies and widths for the $2 \mathrm{p} 3 \mathrm{~s}, 2 \mathrm{p} 3 \mathrm{p}$ resonances in the beryllium spectrum.
Table 2

The energy position $E$, width $\Gamma$ of the Be 2 p3s, $2 p 3 p$ resonances (see text)

\begin{tabular}{|c|c|c|c|c|c|c|}
\hline nl & $\begin{array}{c}\text { Exp, } \\
\text { WLB }\end{array}$ & $\begin{array}{c}\text { Exp, } \\
(\text { EMR }) \\
(\mathrm{ME})\end{array}$ & $\begin{array}{c}\text { Th, } \\
\text { TSB }\end{array}$ & $\begin{array}{c}\text { Th, } \\
\text { CHC }\end{array}$ & $\begin{array}{c}\text { Th, } \\
\text { KTZM }\end{array}$ & $\begin{array}{c}\text { Our } \\
\text { data }\end{array}$ \\
\hline $3 \mathrm{~s}$ & 10.889 & $\begin{array}{c}10.93 \\
10.71\end{array}$ & 10.915 & 10.63 & 10.910 & 10.903 \\
\hline $3 p$ & $531(10)$ & - & 606 & - & 473 & 478 \\
\hline
\end{tabular}

The experimental (by Wehlitz-Lukic-Bluett, WLB; by Mehlman-Balloffet-Esteva, ME; by Esteva-Mehlman-Balloffet-Romand, EMR) and alternative theoretical data by Chi-Huang- Cheng (CHC), Tully-Seaton-Berrington (TSB) and by Kim- Tayal-Zhou-Manson (KTZM) are taken from Ref. [4].In whole a detailed analysis shows quite physically reasonable agreement between the presented theoretical and experimental results. But some difference, in our opinion, can be explained by different accuracy of estimates of the radial integrals, using the different type basis's (different degree of the gauge invariance performance), degree of accounting for the exchange-correlation effects and some other additional computing approximations.

\section{References}

1. Smirnov A.V., Buyadzhi V.V., Ignatenko A.V., Glushkov A.V., Svinarenko A.A., Spectroscopy of the complex autoionization resonances in spectrum of beryllium// Photoelectronics.-2016.Vol.25.-P.26-33.

2. Glushkov A., Svinarenko A., Ternovsky V., Smirnov A.V. , Zaichko P., Spectroscopy of the complex autoionization resonances in spectrum of helium: Test and new spectral data// Photoelectronics .-2015.-Vol.24.-P.94-102.

3. Luc Koenig E., Aymar M., Van Leeuwen R., Ubachs W., Hogervorst W.//Phys. Rev.A.-1995.-Vol.52.-P.208-215. 
4. Wehlitz R., Lukic D., Bluett J.B., Resonance parameters of autoionizing Be 2pnl states// Phys.Rev.A.-2003.Vol.65.-P. 052708.

5. SakhoI., Konté K., Ndao A.S., Biaye M., Wagué A., Calculations of $(\mathrm{nl})^{2}$ and (3lnl') autoionizing states in twoelectron systems//Phys.Scripta.-2010.Vol.82.-P. 035301 (8pp)

6. Ho Y.K., Autoionizing ${ }^{1} \mathrm{P}^{0}$ states of $\mathrm{He}$ between the $\mathrm{N}=2,3$ threshold $\mathrm{He}^{+} / /$Phys. Rev.A.- 1991.-Vol.44.-P.4154-4161.

7. Glushkov A.V., Relativistic Quantum Theory. Quantum mechanics of Atomic Systems.-Odessa: Astroprint, 2008. $700 \mathrm{P}$.

8. Ivanova E.P., Ivanov L.N., Glushkov A.V., Kramida A.E., High Order Corrections in the Relativistic Perturbation Theory with the Model Zeroth Approximation, Mg-Like and Ne-Like Ions//Phys.Scripta.-1985.-Vol.32,N5.P.513-522.

9. Ivanova E.P., Ivanov L.N., Aglitsky E.V., Modern Trends in Spectroscopy of multi-charged Ions// Phys.Rep.-1988.Vol.166,N6.-P.315-390.

10. Glushkov A.V., Ivanov L.N., Ivanova E.P., Radiation decay of atomic states. Generalized energy approach// Autoionization Phenomena in Atoms.- M.: Moscow State University.-1986. -P.58160.

11. Glushkov A.V., Ivanov L.N., Radiation decay of atomic states: atomic residue polarization and gauge noninvariant contributions//Phys.Lett.A.-1992.-Vol. 170, N1.-P.33-36.

12. Ivanov L.N., Ivanova E.P., Knight L., Energy approach to consistent QED theory for calculation of electron-collision strengths// Phys. Rev.A.-1993.Vol. 48.-P.4365-4374.

13. Glushkov A.V., Khetselius O.Yu., Svinarenko A.A., Relativistic theory of cooperative muon-gamma-nuclear processes: Negative muon capture and metastable nucleus discharge// Advances in the Theory of Quantum Systems in Chemistry and Physics
(Springer).-2012.-Vol.22.-P.51-68.

14. Glushkov A.V., Khetselius O.Yu., Loboda A.V., Svinarenko A.A., QED approach to atoms in a laser field: Multiphoton resonances and above threshold ionization//Frontiers in Quantum Systems in Chemistry and Physics (Springer).-2008.-Vol.18.-P.543-560.

15. Glushkov A.V., Svinarenko A.A., Ignatenko A.V., Spectroscopy of autoionization resonances in spectra of the lanthanides atoms// Photoelectronics.-2011.Vol.20.-P. 90-94.

16. Svinarenko A.A., Nikola L.V., Prepelitsa G.P., Tkach T., Mischenko E., The Auger (autoionization) decay of excited states in spectra of multicharged ions: Relativistic theory//Spectral Lines Shape.-2010.-Vol.16.-P.94-98

17. Svinarenko A.A., Spectroscopy of autoionization resonances in spectra of barium: New spectral data // Phototelectronics.-2014.-Vol.23.P.85-90.

18. Malinovskaya S V, Glushkov A V, Khetselius O Yu, Svinarenko A A, Mischenko E.V., Florko T.A., Optimized perturbation theory scheme for calculating the interatomic potentials and hyperfine lines shift for heavy atoms in the buffer inert gas//Int. Journ.of Quantum Chemistry.-2009.-Vol.109, Issue 14.P.3325-3329.

19. Glushkov A V, Ambrosov S V, Loboda A V, Chernyakova Yu, Svinarenko A A , Khetselius O Yu, QED calculation of the superheavy elements ions: energy levels, radiative corrections, and hfs for different nuclear models//Journal Nucl. Phys. A.: nucl. and hadr. Phys.-2004.Vol.734.-P.21

20. Glushkov A.V., Khetselius O.Y., Malinovskaya S.V., New laser-electron nuclear effects in the nuclear $\gamma$ transition spectra in atomic and molecular systems//Frontiers in Quantum Systems in Chemistry and Physics (Springer).-2008.-Vol.18.-P.525-541.

21. Khetselius O.Yu., Relativistic perturbation theory calculation of the hyperfine 
structure parameters for some heavy-element isotopes//Int. Journ. of Quantum Chemistry.-2009.-Vol.109, Issue 14.P.3330-3335.

22. Glushkov A V, Ivanov L N, DC Strong Field Stark Effect for Non-hydrogenic Atoms: Consistent Quantum Mechanical Approach // Journal of Physics B: Atomic, Molecular and Optical Phys.-1993.-Vol.26,N14.-P.L379 L386.

23. Glushkov A.V., Relativistic and correlation effects in spectra of atomic systems.-Odessa: Astroprint.-2006.400P.

24. Glushkov A.V., Atom in electromagnetic field.-Kiev: KNT, 2005.

25. Glushkov A.V., Malinovskaya S.V., Sukharev D.E., Khetselius O.Yu., Loboda A.V., Lovett L., Green's function method in quantum chemistry: New numerical algorithm for the Dirac equation with complex energy and Fermimodel nuclear potential//Int. Journ. Quant. Chem.-2009.- Vol. 109, N8.P.1717-1727.

26. Glushkov A.V., Kondratenko P.A., Lepikh Ya., Fedchuk A.P., Svinarenko A.A., Lovett L., Electrodynamical and quantum - chemical approaches to modelling the electrochemical and catalytic processes on metals, metal alloys and semiconductors//Int. Journ. Quantum Chem..-2009.-Vol.109,N14.P.3473-3481.

27. Khetselius O.Yu., Relativistic calculating the hyperfine structure parameters for heavy-elements and laser detecting the isotopes and nuclear reaction products//Phys.Scripta.-2009.-T.135.P.014023.

28. Glushkov A.V., Khetselius O.Yu., Lovett L., Electron- $\beta$-Nuclear Spectroscopy of Atoms and Molecules and Chemical Bond Effect on the $\beta$-Decay parameters// Advances in the Theory of Atomic and Molecular Systems Dynamics, Spectroscopy, Clusters, and Nanostructures. Series: Progress in Theor. Chem. and Phys., Eds. Piecuch P., Maruani J., Delgado-Barrio G., Wilson
S. (Springer).-2009.-Vol.20.-P.125-152.

29. Glushkov A.V., Svinarenko A.A., Khetselius O.Yu., Buyadzhi V.V., Florko T.A., Shakhman A.N., Relativistic Quantum Chemistry: Advanced approach to construction of the Green's function of the Dirac equation with complex energy and mean-field nuclear potential// Frontiers in Quantum Methods and Applications in Chem. and Physics. Ser.: Progress in Theor. Chem. and Phys., Eds. M. Nascimento, J.Maruani, E.Brändas, G. Delgado-Barrio (Springer).-2015-Vol.29.-P.197-217.

30. Khetselius O.Yu., Optimized perturbation theory to calculating the hyperfine line shift and broadening for heavy atoms in the buffer gas// Frontiers in Quantum Methods and Applications in Chemistry and Physics. Ser.: Progress in Theor. Chem. and Phys., Eds. M.Nascimento, J.Maruani, E.Brändas, G.Delgado-Barrio (Springer).-2015-Vol.29.-P.55-76.

31. Glushkov A.V., Malinovskaya S.V., New approach to the formation of model potential for valence-electrons// Zhurn.Fizich.Khimii.-1988.-Vol.62(1).P.100-104.

32. Glushkov A.V.,Lepikh Ya.I.,Khetselius O.Yu., Fedchuk A.P., Ambrosov S.V, Ignatenko A.V., Wannier-mott excitons and atoms in a DC elecric field: photoionization, Stark effect, resonances in the ionization continuum// Sensor Electr. and Microsyst. Techn.-2008.N4.-P.5-11.

33. Khetselius O.Yu., Relativistic energy approach to cooperative electron$\gamma$-nuclear processes: NEET Effect// Quantum Systems in Chemistry and Physics: Progress in Methods and Applications. Ser.: Progress in Theor. Chem. and Phys., Eds. K.Nishikawa, J. Maruani, E.Brandas, G. Delgado-Barrio, P.Piecuch (Springer).-2012-Vol.26.P.217-229.

34. Malinovskaya S.V., Glushkov A.V., Khetselius O.Yu., Svinarenko A., Bakunina E.V., Florko T.A., The optimized perturbation theory scheme for calculating interatomic potentials 
and hyperfine lines shift for heavy atoms in buffer inert gas//Int. Journ.of Quantum Chemistry.-2009.-Vol.109.P.3325-3329.

35. Khetselius O.Yu., Relativistic perturbation theory calculation of the hyperfine structure parameters for some heavyelement isotopes//Int. Journ. of Quantum Chemistry.-2009.-Vol.109,N14.P.3330-3335.

36. Glushkov A.V., Svinarenko A.A., Khetselius O.Y., Buyadzhi V.V., Florko T.A., Shakhman A., Relativistic quantum chemistry: An Advanced approach to the construction of the Green function of the Dirac equation with complex energy and mean-field nuclear potential// Frontiers in Quantum Methods and Applications in Chemistry and Physics.-2015.Vol.29.-P.197-217.

37. Ternovsky V.B., Glushkov A.V., Zaichko P., Khetselius O.Yu., Florko T.A., New relativistic model potential approach to sensing radiative transitions probabilities in spectra of heavy Rydberg atomic systems/ // Sensor Electr. and Microsyst. Techn.-2015.Vol.12,N4.-P.19-26.

38. Buyadzhi V.V., Glushkov A.V., Mansarliysky V.F., Ignatenko A.V., Svinarenko A.A., Spectroscopy of atoms in a strong laser field: New method to sensing AC Stark effect, multiphoton resonances parameters and ionization crosssections//Sensor Electr. and Microsyst. Techn.-2015.-Vol.12,N4.-P.27-36.

39. Glushkov A.V., Mansarliysky V.F., Khetselius O.Yu., Ignatenko A.V., Smirnov A., Prepelitsa G., Collisional shift of hyperfine line for thallium in an atmosphere of the buffer inert gas//J. Phys.: Conf. Ser. (IOP).-2017.Vol.810.-P. 012034.

40. Buyadzhi V.V., Zaichko P.A., Gurskaya M., Kuznetsova A.A., Ponomarenko E.L., Ternovsky E.,Relativistic theory of excitation and ionization of Rydberg atoms in a Black-body radiation field//J. Phys.: Conf. Series.-2017.-Vol.810.-P. 012047.

41. Ivanova E P, Glushkov A V, Theoretical investigation of spectra of multicharged ions of F-like and Ne-like isoelectronic sequences// Journal of Quantitative Spectroscopy and Radiative Transfer.1986.-Vol.36, Issue 2.-P. 127-145.

42. Svinarenko A.A., Study of spectra for lanthanides atoms with relativistic many- body perturbation theory: Rydberg resonances// J. Phys.: Conf. Ser. - 2014.-Vol.548.-P.012039.

43. Svinarenko A.A., Ignatenko A.V., Ternovsky V.B., Nikola V.V., Seredenko S.S., Tkach T.B., Advanced relativistic model potential approach to calculation of radiation transition parameters in spectra of multicharged ions// J. Phys.: Conf. Ser. -2014.-Vol.548.-P. 012047.

44. Svinarenko A.A., Khetselius O.Yu., Buyadzhi V.V., Florko T.A., Zaichko P.A., Ponomarenko E.L., Spectroscopy of Rydberg atoms in a Black-body radiation field: Relativistic theory of excitation and ionization// J. Phys.: Conf. Ser.-2014.-Vol.548.-P. 012048.

45. Glushkov A.V., Khetselius O.Yu., Bunuakova Yu.Ya., Buyadzhi V.V, Brusentseva S.V., Zaichko P.A., Sensing interaction dynamics of chaotic systems within a chaos theory and microsystem technology Geomath with application to neurophysiological systems// Sensor Electr. and Microsyst.Techn.-2014.Vol. 11,N3.-P.62-69.

46. Prepelitsa G.P., Glushkov A.V., Lepikh Ya.I., Buyadzhi V.V., Ternovsky V.B., Zaichko P.A., Chaotic dynamics of nonlinear processes in atomic and molecular systems in electromagnetic field and semiconductor and fiber laser devices: new approaches, uniformity and charm of chaos// Sensor Electr. and Microsyst. Techn.-2014.-Vol.11,N4.-P.43-57.

47. Khetselius O.Yu., Hyperfine structure of atomic spectra.-Odessa: Astroprint, 2008.-210P.

48. Khetselius O.Yu., Hyperfine structure of radium $/ /$ Photoelectronics.-2005.N14.-P.83-85.

49. Khetselius O., Spectroscopy of cooperative electron-gamma-nuclear processes in heavy atoms: NEET effect// J. Phys.: 
Conf. Ser.-2012.- Vol.397.-P.012012

50. Khetselius O.Yu., Florko T.A., Svinarenko A.A., Tkach T.B., Radiative and collisional spectroscopy of hyperfine lines of the Li-like heavy ions and $\mathrm{Tl}$ atom in an atmosphere of inert gas//Phys.Scripta.-2013.-Vol.T153P.014037.

51. Khetselius O.Yu., Turin A.V., Sukharev D.E., Florko T.A., Estimating of Xray spectra for kaonic atoms as tool for sensing the nuclear structure// Sensor Electr. and Microsyst. Techn.-2009.N1.-P.30-35.

52. Khetselius O.Yu., On possibility of sensing nuclei of the rare isotopes by means of laser spectroscopy of hyperfine structure//Sensor Electr. and Microsyst.Techn.-2008.-Vol.3.-P.28-33.

53. Glushkov A V, Malinovskaya S V, Gurnitskaya E P, Khetselius O Yu, Dubrovskaya $\mathrm{Yu} \mathrm{V}$, Consistent quantum theory of recoil induced excitation and ionization in atoms during capture of neutron// Journal of Physics: Conf. Series (IOP).-2006.-Vol.35.-P.425-430.

54. Glushkov A.V., Khetselius O.Y., Brusentseva S.V., Zaichko P.A., Ternovsky V.B., Studying interaction dynamics of chaotic systems within a non-linear prediction method: application to neurophysiology// Advances in Neural Networks, Fuzzy Systems and Artificial Intelligence, Ser: Recent Adv. in Computer Engineering, Ed. J.Balicki.-2014.Vol.21.-P.69-75.

55. Khetselius O.Yu., Quantum Geometry: New approach to quantization of the quasistationary states of Dirac equation for super heavy ion and calculating hyperfine structure parameters// Proc. Int. Geometry Center.-2012.-Vol.5, № 3-4.P.39-45.

56. Khetselius O Yu, Relativistic calculation of the hyperfine structure parameters for heavy elements and laser detection of the heavy isotopes// Phys. Scripta.2009.-Vol.T135.-P. 014023.

57. Glushkov A.V., Khetselius O.Yu., Gurnitskaya E.P., Loboda A.V., Florko T.A., Sukharev D.E., Lovett L., Gauge-
Invariant QED Perturbation Theory Approach to Calculating Nuclear Electric Quadrupole Moments, Hyperfine Structure Constants for Heavy Atoms and Ions//Frontiers in Quantum Systems in Chemistry and Physics, Series: Progress in Theoretical Chemistry and Physics (Springer), 2008.-Vol.18.-P.507-524.

58. Glushkov A.V., Ambrosov S.V., Loboda A.V., Gurnitskaya E.P., Prepelitsa G.P., Consistent QED approach to calculation of electron-collision excitation cross sections and strengths: Ne-like ions// Int. Journal Quantum Chem.2005.-Vol.104, Issue 4.-P.562-569.

59. Glushkov A.V., Khetselius O.Yu., Malinovskaya S.V., Optics and spectroscopy of cooperative laser-electron nuclear processes in atomic and molecular systems - new trend in quantum optics// Europ. Phys. Journ. ST.-2008.-Vol. 160, Issue 1.-P.195-204.

60. Glushkov A.V., Ambrosov S.V., Ignatenko A.V., Korchevsky D.A., DC Strong Field Stark Effect for nonhydrogenic Atoms: Consistent Quantum Mechanical Approach // Int. Journ. Quant. Chem.-2004.-Vol.99,N6.-P.936-939.

61. Glushkov A.V., Khetselius O.Yu., Svinarenko A.A., Theoretical spectroscopy of autoionization resonances in spectra of lanthanide atoms// Physica Scripta.2013.-Vol.T153.-P.014029.

62. Glushkov A.V., Khetselius O.Yu., Gurnitskaya E.P., Loboda A.V., Sukharev D.E., Relativistic quantum chemistry of heavy ions and hadronic atomic systems: spectra and energy shifts// Theory and Applications of Computational Chemistry. AIP Conference Proceedings.-2009.-Vol.1102.P.168-171.

63. Khetselius O.Yu., Relativistic calculating the spectral lines hyperfine structure parameters for heavy ions//Spectral Line Shapes, AIP Conf. Proceedings.-2008.Vol.1058.-P.363-365.

64. Khetselius O.Yu., Glushkov A.V., Gurnitskaya E.P., Loboda A.V., Mischenko E.V., Florko T.A., Sukharev D.E., Collisional Shift of the $\mathrm{Tl}$ hyperfine lines in 
atmosphere of inert gases// Spectral Line Shapes, AIP Conf. Proceedings.-2008.Vol.1058.-P.231-233.

65. Khetselius O.Yu., Hyperfine structure of energy levels for isotopes $73 \mathrm{Ge}$, 75As, $201 \mathrm{Hg} / /$ Photoelectronics.-2007.N16.-P.129-132.

66. Glushkov A.V., Operator Perturbation Theory for Atomic Systems in a Strong DC Electric Field // Advances in Quantum Methods and Applications in Chemistry, Physics, and Biology. Series: Frontiers in Theoretical Physics and Chemistry, Eds. M.Hotokka, J.Maruani, E. Brändas, G.Delgado-Barrio (Springer).-2013.-Vol. 27.-P.161177.

67. Glushkov A.V., Svinarenko A.A., Buyadzhi V.V., Zaichko P., Ternovsky V., Chaos-geometric attractor and quantum neural networks approach to simulation chaotic evolutionary dynamics during perception process// Advances in Neural Networks, Fuzzy Systems and Artificial Intelligence, Series: Recent Advances in Computer Engineering, Ed. J.Balicki.-2014.-Vol.21.-P.143-150.

68. Glushkov A.V.,Malinovskaya S.V., Chernyakova Yu.G., Svinarenko A.A. Cooperative laser-electron-nuclear processes: QED calculation of electron satellites spectra for multi-charged ion in laser field//Int. Journ. Quant. Chem.2004.-Vol. 99,N6.-P.889-893.

69. Glushkov A V, Negative ions of inert gases// JETP Lett.-1992.-Vol.55, Issue 2.-P.97-100.

70. Khetselius O.Y., Gurnitskaya E.P., Sensing the electric and magnetic moments of a nucleus in the N-like ion of $\mathrm{Bi} / /$ Sensor Electr. and Microsyst. Techn.-2006.-N3.-P.35-39.

71. Khetselius O.Y., Gurnitskaya E.P., Sensing the hyperfine structure and nuclear quadrupole moment for radium// Sensor Electr. and Microsyst. Techn.-2006.N2.-P.25-29.

72. Florko T.A., Loboda A.V., Svinarenko A.A., Sensing forbidden transitions in spectra of some heavy atoms and multicharged ions: New theoretical scheme// Sensor Electr. and Microsyst. Techn.-2009.-N3.-P.10-15.

73. Glushkov A.V., Energy Approach to Resonance states of compound superheavy nucleus and EPPP in heavy nuclei collisions// Low Energy Antiproton Phys. AIP Conference Proceedings.2005.-Vol.796 (1).-P.206-210.

74. Sukharev D.E., Khetselius O.Yu., Dubrovskaya Yu.V., Sensing strong interaction effects in spectroscopy of hadronic atoms// Sensor Electr. and $\mathrm{Mi}-$ crosyst. Techn.-2009.-N3.-P.16-21.

UDC 539.183

A. V. Smirnov, O. Yu. Khetselius, V. V. Buyadzhi, A. S. Belodonov

\title{
ADVANCED RELATIVISTIC APPROACH IN SPECTROSCOPY OF COMPLEX AUTOIONIZATION RESONANCES IN ATOMIC SPECTRA
}

\begin{abstract}
We present an advanced relativistic approach to to studying autoionization resonances parameters in the atomic systems, which is based on an generalized energy approach (Gell-Mann and Low S-matrix formalism) combined with the relativistic multi-quasiparticle perturbation theory with the Dirac-Kohn-Sham zeroth approximation and accurate accounting for the exchange-correlation, relativistic corrections. The optimization of relativistic orbitals base is reduced to minimization of the gauge dependent multielectron contribution of the lowest QED PT corrections to the radiation widths of atomic levels, which in their turn leads to the Dirac-Kohn-Sham-like equations for the electron
\end{abstract}


density. As illustration of an advanced approach application there are presented the results on energy and width for the autoionization resonance $3 \mathrm{~s} 3 \mathrm{p}^{1} \mathrm{P}_{0}$ in helium He atom spectrum, namely, the available experimental data and those results of other theories, including, method of complex rotation by Ho, algebraic approach by Wakid-Callaway, diagonalization method by Senashenko-Wague etc.

Key words: spectroscopy of autoionization resonances, advanced relativistic approach, helium

УДК 539.183

А. В. Смирнов, О. Ю. Хецелиус, В. В. Буяджси, А. С. Белодонов

\section{УСОВЕРШЕНСТВОВАННЫЙ РЕЛЯТИВИСТСКИЙ ПОДХОД В СПЕКТРОСКОПИИ СЛОЖНЫХ АВТОИОНИЗАЦИОННЫХ РЕЗОНАНСОВ В АТОМНЫХ СПЕКТРАХ}

\section{Резюме}

В работе развивается усовершенствованный релятивистский подход к изучению параметров автоионизационных резонансов в атомных системах, который основывается на обобщенном энергетическом подходе (S-матричный формализм Гелл-Манна и Лоу) и релятивистской многочастичной теорией возмущений с нулевым приближением Дирака-Кона-Шэма и аккуратным учетом обменно-корреляционных, релятивистских эффектов. Оптимизация базиса релятивистских орбиталей сводится к минимизации калибровочно-зависимого многоэлектронного вклада от обменно-корреляционных поправок КЭД теории возмущений в радиационные ширины атомных уровней, что в свою очередь, сводится к решению системы уравнений типа ДиракаКона-Шэма для электронной плотности. В качестве иллюстрации возможностей предлагаемого подхода приведены данные по энергии и ширине автоионизационного резонанса $3 \mathrm{~s} 3 \mathrm{p}{ }^{1} \mathrm{P}_{0}$ в спектре атома гелия и проведено сравнение с имеющимися экспериментальными данными и результатами других теорий, в том числе, методом комплексного вращения Хо алгебраического подхода Wakid-Callaway, метода диагонализации Senashenko-Wague и т.д.

Ключевые слова: спектроскопия автоионизационных резонансов, усовершенствованный релятивистский подход, гелий

УДК 539.183

А. В. Смірнов О. Ю. Хецеліус, В. В. Буяджи, О. С. Белодонов

\section{УДОСКОНАЛЕНИЙ РЕЛЯТИВІСТСЬКИЙ ПІДХІД В СПЕКТРОСКОПІЇ СКЛАДНИХ АВТОІОНІЗАЦІЙНИХ РЕЗОНАНСІВ В АТОМНИХ СПЕКТРАХ}

\section{Резюме}

В роботі розвивається вдосконалений релятивістський підхід до вивчення параметрів автоіонізаціонних резонансів в атомних системах, який грунтується на узагальненому енергетичному підході (S-матричний формалізм Гелл-Манна і Лоу) і релятивістської багаточастинковій теорії 
збурень з нульовим наближенням Дірака-Кона-Шема і акуратним урахуванням обмінно- кореляційних, релятивістських ефектів. Оптимізація базису релятивістських орбіталей зводиться до мінімізації калібрувально-залежного багатоелектронного вкладу від обмінно-кореляційних поправок КЕД теорії збурень в радіаційні ширини атомних рівнів, що в свою чергу, зводиться до вирішення системи рівнянь типу Дірака-Кона-Шема для електронної густини. В якості ілюстрації можливостей запропонованого підходу наведені дані по енергії і ширині автоіонізаційного резонансу $3 \mathrm{~s} 3 \mathrm{p}{ }^{1} \mathrm{P}_{0}$ в спектрі атома гелію і проведено порівняння з наявними експериментальними даними і результатами інших теорій, в тому числі, методом комплексного обертання Хо, алгебраїчного підходу Wakid-Callaway, методу діагоналізації Senashenko-Wague i т.i.

Ключові слова: спектроскопія автоіонізаційних резонансів, удосконалений релятивістський підхід, гелій 